\title{
BIHON TYPE NOODLES FROM HEAT MOISTURE TREATED STARCH OF FOUR VARIETIES OF SWEET POTATO
}

\author{
[Mi Tipe Bihun dari Pati Heat Moisture Treatment dari Empat Varietas Ubi Jalar]
}

\author{
Vera Apryana Lase, Elisa Julianti* dan Linda Masniary Lubis \\ Department of Food Science and Technology, Faculty of Agriculture, University of Sumatera Utara, Medan
}

Accepted February $21^{\text {th }} 2013$ / Approved August $19^{\text {th }} 2013$

\begin{abstract}
Sweet potato starch has limited uses in food industry, but modification of its properties may make it more suitable for use especially for starch based food such as bihon type noodle. The objective of this research was to study the effect of heat moisture treated starch from 4 varieties of sweet potato on the quality of its bihon type noodle. Four different varieties of sweet potato i.e. white, yellow, orange and purple tuber were treated with heat moisture treatment (HMT). The HMT was performed by exposing the starch to high temperature $\left(110^{\circ} \mathrm{C}\right.$ for 3 hours $)$ at a moisture content of $25 \%$. The HMT modified sweet potato starch was then processed into bihon type noodle. As a control, a commercial bihon type noodle made from rice starch was used. Parameters evaluated were the modified starch and bihon properties. The results showed that the modification of starch with HMT could increase the peak viscosity, setback viscosity, final viscosity and gelatinization temperature but lower the value of the breakdown viscosity. The best bihon from the four varieties of sweet potatoes was that made from white sweet potato starch because it has low cooking losses, low fat, but has high color/brightness and is preferred by panelist.
\end{abstract}

Keywords: bihon, heat moisture treatment, starch, sweet potatoes

\begin{abstract}
ABSTRAK
Keterbatasan pemanfaatan pati alami di dalam industri pangan dapat diatasi dengan cara modifikasi pati sehingga dihasilkan pati dengan karakteristik yang diinginkan terutama pada produk pangan berbahan dasar pati seperti bihun instan. Penelitian ini bertujuan untuk mempelajari pengaruh varietas ubi jalar terhadap karakteristik bihun instan yang dibuat dari pati ubi jalar yang dimodifikasi dengan heat moisture treatment. 4 varietas ubi jalar yang digunakan yaitu ubi jalar berdaging umbi putih, kuning, orange dan ungu. Proses modifikasi pati dengan heat moisture treatment (HMT) dilakukan dengan cara mengatur kadar air pati hinggai $25 \%$ dan dipanaskan pada suhu $110^{\circ} \mathrm{C}$ selama 3 jam, kemudian dilakukan karakterisasi fisikokimia dan fungsional pati termodifikasi, dan pembuatan bihun instan serta karakterisasi bihun instan dari pati termodifikasi HMT 4 varietas ubi jalar dengan menggunakan bihun instan komersial sebagai kontrol. Hasil penelitian menunjukkan modifikasi pati ubi jalar dengan HMT akan meningkatkan viskositas puncak, viskositas balik, viskositas akhir dan suhu gelatinisasi, tetapi akan menurunkan nilai viskositas breakdown dari pati pada keempat varietas ubi jalar. Pati ubi jalar dari varietas berdaging umbi putih yang dimodifikasi dengan HMT menghasilkan bihun instan terbaik dengan nilai kehilangan akibat pemasakan dan kadar lemak yang rendah tetapi memiliki warna dan kecerahan yang lebih tinggi serta lebih disukai oleh panelis.
\end{abstract}

Kata kunci: bihun, heat moisture treatment, pati, ubi jalar

\section{INTRODUCTION}

Sweet potato is an important root crop in Indonesia and other developing countries. Asia is the largest sweet potato producing region with 125 million tons of annual production. China accounts for about $90 \%$ of worldwide sweet potato production with an annual production of 117 million tons (IPC, 2011). Total production of sweet potato in Indonesia in 2011 was 2.196 tons, of which 191 tons was produced in North Sumatera (Statistics Indonesia of Republic Indonesia, 2012).

Sweet potato are rich in starch (6.9-30.7\% on wet basis or 50-80\% on dry basis) (Chen et al. 2003; Aprianita et al. 2009;

Paper Presented at International Conference on "Future of Food Factors", October 3-4, 2012, Jakarta, Indonesia.

${ }^{*}$ Corresponding Author:

E-mail: elizayulianti@yahoo.com; Phone: +6281361033610
Zhu et al. 2011). Starch plays a vital role in developing food products either as a raw material or as a food additive such as thickener, stabilizer or texture enhancer (Aina et al. 2012). In China, sweet potato roots and its products have been widely used in starch noodles, bakery foods, snack foods, confectionery products, starch syrup production, alcohol production and in the brewing industries (Chen et al. 2003), whereas in Indonesia usually are used for household consumption either in boiled, fried or roasted form due to low level of processing and industrial utilization.

Sweet potato starch granules are round polygonal, polygonal, spherical and oval round with size ranging between 2-72 $\mu \mathrm{m}$ (Chen et al. 2003; Thao and Noomhorm, 2011; Odeku, 2013). Starch from sweet potato, cassava, potato and arrowroot is more free swelling and non-congealing. It also exhibits a Type A Brabender amylograph. Type A amylograph is characterised by a high pasting peak followed by rapid and 
major thinning on cooling (Collado et al. 2001). This characteristics limit its utilization in product that require starches with faster retrogradation rates like starch noodle. Gelatinization temperatures of sweet potato starches are reported in the range of $54^{\circ} \mathrm{C}$ to $75^{\circ} \mathrm{C}$ (Chen et al. 2003; Kitahara et al. 2005; Oladebeye et al. 2009).

Modification of starch by physical include heat gelatinization and chemical methods include enzymatic hydrolysis, acid hydrolysis and other various form of chemical modification may make it more suitable for use in traditional products that normally use other type of starches. Physical methods (heattreatment) were the interest because chemical reagents are not required to impart a modifying effect and therefore, relatively cheaper to produce.

Heat Moisture Treatment (HMT) involves heating starch at temperature above its gelatinization point but with insufficient moisture to cause gelatinization (Haghayegh and Schoenlechner, 2011). Modification of sago starch by HMT was done at $25 \%$ moisture content (Purwani et al. 2006) or $20 \%$ moisture content and heated at 100,110 or $120^{\circ} \mathrm{C}$ of temperature (Pukkahuta and Varavinit, 2007). Modification of sweet potato starch by HMT decreased swelling and solubility of red sorghum starch but increased water absorption capacity and pasting temperature of the starch (Adebowale et al. 2005). HMT will also change the pasta profile of starch from Type $A$ to Type C (Tsakama et al. 2011) or from Type A to Type B (Purwani et al. 2006) of Brabender Amylograph. The use of this process has the potential of giving starch desired physical properties for application in the manufacture of various starch based products, especially in acid food and retorded foods (Takashi et al. 2005), including the bihon type noodles (Collado et al. 2001).

Bihon is made from gluten free starch and usualy made from mung bean or rice starch. It is favorably consumed as a main dish or snack by people in Indonesia and other South East Asia countries. Stach noodles are a source of resistant starch (RS) since they are retrograded. Resistant starch has been defined formally as the fraction of dietary starch that is not digested in the small intestine of healthy individuals (Koksel et al. 2008; Lee and Shin, 2006; Sajilata et al. 2006).

Heat moisture treatment consists of autoclaving-cooling and cross-linking can be applied to obtain resistant starches and improve the yield of resistant starches (Abdoulaye et al. 2012; Aparicio-Saguilan et al. 2005; Onyango et al. 2006). The bihon dough is made from $5 \%$ pregelatinized starch (acting as the gluten in wheat flour dough) mixed with $95 \%$ of the remaining (native) starch and water to a dough. The starch itself plays an essential role in both starch noodle processing and the final starch noodle quality (Collado et al. 2001). The objective of this research was to study the effect of sweet potato variety on quality of bihon type noodle made from heat moisture treatment (HMT) starch.

\section{MATERIALS AND METHODS}

\author{
Materials \\ Sweet potato from four typical varities of sweet potato, each \\ is difference in tuber color i.e. white, yellow, orange and purple
}

tuber obtained from local market in Medan. The chemicals used for starch and modified starch analysys.

\section{Isolation of starch}

Starches were isolated according to Collado and Corke (1999) method with a little modification. Each kind of sweet potato tuber was washed thoroughly, macerated using mechanized grater, diluted 1:2 w/v with tap water and filtered through cheesecloth. Starch in the filtrate was allowed to settle for $12 \mathrm{~h}$ at room temperature $\left(27-30^{\circ} \mathrm{C}\right)$. The supernatant was decanted and discarded while the starch was resuspended in water and kept at room temperature for $6 \mathrm{~h}$ to settle. The starch sediment was dried in a convection oven at $50^{\circ} \mathrm{C}$ overnight, cooled to room temperature, and equilibrated for 4 hours before samples were packed and sealed in polyethylene.

\section{Characterization of physicochemical properties of starch}

Native and HMT starch was analyzed for moisture (AACC, 1995), degree of acidity (BSN, 1989; SNI: 06-1451), color/whiteness by using Whiteness Meter (Kett Electric Laboratory C-100-3), size and shape of starch granule by using polarized light microscope (Olympus Optical Co.Ltd, Japan). Water and oil absorption index were determined according to the method of Adebowale and Lawal (2004). Starch samples (1 g) were suspended in $5 \mathrm{ml}$ water (for water absorption index) or vegetable oil (for oil absorption index) in a centrifuge tube. The slurry was shaken on a platform tube rocker for $1 \mathrm{~min}$ at room temperature and centrifuged at $3000 \mathrm{rpm}$ for 10 minutes. The supernatant was poured carefully into a tared evaporating dish. Water or oil absorption index was calculated as $\mathrm{g}$ water or vegetable oil absorbed by $1 \mathrm{~g}$ dry sample. Paste clarity was determined according to Ceballos et al. (2007), by boiling $1 \%$ aqueous solution of starch at $93^{\circ} \mathrm{C}$ with repeated shaking for 30 $\mathrm{min}$. The solution was cooled and then transferred into a cuvette and transmittance was measured at $650 \mathrm{~nm}$ using a spectrophotometer.

Solubility of starch was determined as follows: Starch $(0.5000 \mathrm{~g})$ was mixed with $15 \mathrm{ml}$ distilled water in a centrifuge tube and heated in an $85^{\circ} \mathrm{C}$ water bath for 15 minutes. The sample was then centrifuged for 15 minutes at $2200 \mathrm{rpm}$. The aliquot was transferred to a pre-weighed beaker and dried at $100^{\circ} \mathrm{C}$. Solubility was calculated according to Muazu et al. 2011.

\section{Properties of starch pasting}

Pasting properties of starch were measured by a Rapid Visco Analyzer (RVA, Model Tecmaster Newport Scientific, Australia). A suspension of $3 \mathrm{~g}$ (14\% w.b.) starch in $25 \mathrm{~g}$ of distilled water underwent a controlled heating-and-cooling cycle under constant shear where it was held at $50^{\circ} \mathrm{C}$ for 1 minutes, heated from 50 to $95^{\circ} \mathrm{C}$ at $6^{\circ} \mathrm{C} /$ minute, held at $95^{\circ} \mathrm{C}$ for 5 minutes. The following data were recorded: pasting parameters of time from onset of pasting to peak viscosity $\left(P_{\text {time }}\right)$; temperature at which peak viscosity was reached $\left(P_{\text {temp }}\right)$; peak viscosity (PV); viscosity at the end of hold time at $95^{\circ} \mathrm{C}$ or hot paste viscosity (HPV); breakdown, PV less than HPV; viscosity at the end of the hold time at $50^{\circ} \mathrm{C}$ or cold paste viscosity (CPV); and setback ratio (CPV/HPV). 


\section{Heat moisture treatment}

The starch from 4 varieties of sweet potato were modified by heat moistue treatment according to Collado et al. (2001) with a little modification. The moisture of sweet potato starch was adjusted to $25 \%$ by adding the distillated water, and equilibrated at $6^{\circ} \mathrm{C}$ for 12 hours (refrigerated condition) and placed in a covered baking pan for 3 hours at $110^{\circ} \mathrm{C}$. The sample was shaken occasionally for even distribution of heat. The sample was cooled to room temperature (about $30^{\circ} \mathrm{C}$ ) and dried at $50^{\circ} \mathrm{C}$ for 4 hours, and sealed in polyethylene bags until use.

\section{Preparation of bihon type-starch noodles}

Bihon-type starch noodles were made from HMT starch from 4 varieties of sweet potato. The starch dough was prepared by partial gelatinization of $20 \%$ (w/w) rice flour of the total HMT starch to be used which serves as binder. Gelatinization was done by boiling rice flour and water $(1: 3 \mathrm{w} / \mathrm{v})$, added $1 \%$ Sodium tripolyphospate and $1 \%$ solution containing $\mathrm{K}_{2} \mathrm{CO}_{3}, \mathrm{Na}_{2} \mathrm{CO}_{3}$ and $\mathrm{KH}_{2} \mathrm{PO}_{4}$ for 5 minutes. Gelatinized starch was then mixed with 80\% ungelatinized HMT starch and 0.5\% Carboxyl Methyl Cellulose (CMC). The dough was kneaded manually for 20 minutes or until a uniform consistency was achieved. The starch dough was extruded using Hand Noodle Maker and steamed at $90^{\circ} \mathrm{C}$ for 3 minutes, dried at $60^{\circ} \mathrm{C}$ for 1 hour in a convection drier, cooled to room temperature, and sealed in polyethylene bags until used for analysis and sensory evaluation.

\section{Noodles characteristics}

Chemical characteristics of the noodles such as proximate analysis (protein content by Micro Kjeldhal, lipid content by Soxhlet Method using hexan as solvent, moisture and ash content and crude fibre (AOAC, 1995). Physical characteristics of the noodles such as texture (elongation) were measured using a Rheometer (RE-3305), color ((Chromameter Minolta Tipe CR-300, Japan), cooking loss and water uptake.

Cooking loss and water uptake of the noodles were determined as described in the AACC (2000) method. $10 \mathrm{~g}$ of the noodles were added to a beaker containing about $200 \mathrm{ml}$ boiling water. The beaker was covered with a watch glass and noodles cooked until optimum cooking was reached. The cooked noodles were alowed to drain and rinsed with water, then drained again for 3 minutes and then weighed $(A)$, dried in the oven at $100^{\circ} \mathrm{C}$ of temperature until the constant weight was reached, then weighed again $(B)$. The cooking loss and water uptake were then calculated as given below:

Cooking loss $(\%)=1-\frac{\text { Constant weight after drying }}{\text { sample weight (1-moisture fraction of noodle) }} \times 100 \%$

$$
\text { Water uptake }(\%)=\frac{(\mathrm{A}-\mathrm{B})-(\text { sample moisture } \mathrm{x} \text { sample weight) }}{\text { sample weight }(1-\text { sample moisture })} \times 100 \%
$$

Sensory evaluation of noodles were done for aroma, taste and texture. Plain bihon type-noodles were boiled and cooked at optimum condition, and presented to 15 semi trained panelists of student at Department of Food Science And Technology University of Sumatera Utara. Panelist preferences were rated in 5-point scales; 1 was extremely disliked and 5 for extremly liked.

\section{Statistical analysis}

Mean data of all parameters evaluated were subjected to an analysis of variance (ANOVA). When significant differences were found, the means were tested by Duncane Multiple Range Test (DMRT). All treatment were done in five replicates.

\section{RESULTS AND DISCUSSION}

\section{Physicochemicals properties of starch}

The physicochemical characteristics of sweet potato starches were presented in Table 1. The moisture content of sweet potato starches both native and HMT starch showed high variation. The low moisture content of native starch from yellow tuber sweet potato $(7.32 \%)$ and modified starch of orange tuber sweet potato $(8.50 \%)$ was an evidence of good drying regime. The moisture content of sweet potato starch was dependant on the process used for drying (Ali et al. 2012). HMT process gave the significant effect $(P<0.05)$ on degree of acidity of starch. HMT starch had a lower degree of acidity for 4 varities of sweet potato compared to native starch. The lower value of degree of acidity caused by the addition water during the HMT, but it inversely proportional to the solubility of (Adebowale et al. 2005).

In order to study the relationship of the color of bihon type noodle with HMT starch, the color and paste clarity of native and HMT starch were determined. There was a significant effect $(P<0.05)$ on the whiteness of modified starch, but there was no difference in whiteness of the native starch (Table 1). Whiteness value of HMT starch in white and purple tuber sweet potato was lower than native starch, but in yellow and orange tuber the whiteness of HMT starch was higher than their native starches. A high value of whiteness is desired for starches.

The size of native starch granules varied from 3-13 $\mu \mathrm{m}$, and the shape was oval, round, spherical, polygonal, and round polygonal. The yellow tuber sweet potato has smaller granules than the others as shown in Figure 1a, 1b, 1c, and 1d. After modification, starch granules swelled and tended to appear as fused and less smooth than the native granules, but in general HMT does not change the size and shape of ganule as shown in Figure $1 \mathrm{e}, 1 \mathrm{f}, 1 \mathrm{~g}$, and $1 \mathrm{~h}$. Similar results were also obtained by Singh et al. (2005), Matos et al. (2009), Adebowale and Lawal (2003) and Pukkahuta et al. (2008). The particle size of starch is one of the important characteristics, which may influence other physicochemical properties such as paste clarity and water absorption index (Singh et al. 2005). With these factors in mind the use of sweet potato starch may be applicable for food industry, especially products require starch that offers a smaller particle size. The previous study has indicated that the fine granules of taro starch improved binding and reduce breakage of a snack product (Huang et al. 2006). 
Table 1. Effect of HMT on the physicochemical characteristics of starch from four varieties of sweet potato

\begin{tabular}{|c|c|c|c|c|c|}
\hline \multirow{2}{*}{ Parameters } & \multirow{2}{*}{ Starch } & \multicolumn{4}{|c|}{ Variety of Sweet Potato } \\
\hline & & White Tuber & Yellow Tuber & Orange Tuber & Purple Tuber \\
\hline \multirow{2}{*}{ Moisture content (\%) } & Native & 15.54 & 7.32 & 11.53 & 10.29 \\
\hline & Modified & 11.24 & 11.78 & 8.50 & 11.32 \\
\hline \multirow[t]{2}{*}{ Degree of acidity } & Native & $2.28 \pm 0.06 \mathrm{a}$ & $2.41 \pm 0.12^{a}$ & $2.22 \pm 0.07$ a & $2.18 \pm 0.19 \mathrm{a}$ \\
\hline & Modified & $2.07 \pm 0.18^{b}$ & $2.04 \pm 0.22 b$ & $1.95 \pm 0.02 b$ & $1.83 \pm 0.01 \mathrm{~b}$ \\
\hline \multirow[t]{2}{*}{ Whiteness (\%) } & Native & $87.79 \pm 0.59$ a & $83.35 \pm 0.20$ a & $74.45 \pm 0.13$ a & $69.98 \pm 0.28$ a \\
\hline & Modified & $85.73 \pm 1.36$ b & $83.67 \pm 0.26 b$ & $75.58 \pm 0.18$ a & $68.68 \pm 1.49 b$ \\
\hline \multirow[t]{2}{*}{ Granule shape } & Native & $\begin{array}{l}\text { Round, oval, spherical, } \\
\text { polygonal round }\end{array}$ & $\begin{array}{l}\text { Round, oval, spherical, } \\
\text { polygonal round }\end{array}$ & $\begin{array}{l}\text { Round, oval, spherical, } \\
\text { polygonal round }\end{array}$ & $\begin{array}{l}\text { Round, oval, spherical, } \\
\text { polygonal round }\end{array}$ \\
\hline & Modified & $\begin{array}{l}\text { Round, oval, spherical, } \\
\text { polygonal round } \\
\text { polygonal }\end{array}$ & $\begin{array}{c}\text { Round, oval, spherical, } \\
\text { polygonal round } \\
\text { polygonal }\end{array}$ & $\begin{array}{c}\text { Round, oval, spherical, } \\
\text { polygonal round } \\
\text { polygonal }\end{array}$ & $\begin{array}{l}\text { Round, oval, spherical, } \\
\text { polygonal round } \\
\text { polygonal }\end{array}$ \\
\hline \multirow[t]{2}{*}{ Granule size $(\mu \mathrm{m})$} & Native & $4-13$ & 3-8 & $3-7$ & 3-10 \\
\hline & Modified & $3-12$ & $3-9$ & $3-9$ & 3-11 \\
\hline \multirow[t]{2}{*}{ Water absorption index $(\mathrm{g} / \mathrm{g})$} & Native & $0.98^{*}$ & $0.98^{*}$ & NR & $0.81^{*}$ \\
\hline & Modified & $2.24 \pm 0.07$ a & $2.32 \pm 0.33 \mathrm{a}$ & $2.28 \pm 0.07 \mathrm{a}$ & $2.32 \pm 0.03 \mathrm{a}$ \\
\hline \multirow[t]{2}{*}{ Oil absorption index (g/g) } & Native & $1.15^{\star}$ & $0.95^{*}$ & $N R$ & $1.04^{*}$ \\
\hline & Modified & $\begin{array}{c}2.25 \pm 0.17 \mathrm{a} \\
2.30 \pm 0,07 \mathrm{ab}, \mathrm{AB} \\
2.14 \pm 0.11 \mathrm{~b}, \mathrm{AB} \\
2.40 \pm 0.04 \mathrm{a}, \mathrm{A}\end{array}$ & $2.30 \pm 0.07 \mathrm{a}$ & $2.14 \pm 0.11 \mathrm{a}$ & $2.40 \pm 0.04$ a \\
\hline \multirow[t]{2}{*}{ Pasta clarity (\%T) } & Native & $\begin{array}{l}8.40 \pm .28^{*} \\
89\end{array}$ & $87.54^{*}$ & NR & $86.14^{*}$ \\
\hline & Modified & $87.04 \pm 0.11$ a & $84.04 \pm 0.11 b$ & $77.08 \pm 0.13^{c}$ & $75.06 \pm 0.15 \mathrm{~d}$ \\
\hline \multirow[t]{2}{*}{ Solubility in cold water (\%) } & Native & NR & NR & NR & NR \\
\hline & Modified & $12.47 \pm 0.21$ a & $11.95 \pm 0.27 \mathrm{a}$ & $12.03 \pm 0.74 \mathrm{a}$ & $12.56 \pm 0.21 \mathrm{a}$ \\
\hline
\end{tabular}

Means in a raw for each variety with the same letters between native and modified starch were not significantly different at $p<0.05$. All the values were the mean of 5 measurements. NR = Not Reported

* Data were taken from Julianti and Ridwansyah (2008)

The water and oil absorption index were higher in the HMT starches than in the native starch. The increasing of water absorption of HMT starch implies that hydrophilic tendency increased with incresing level of moisture treatment (Adebowale et al. 2005). The major component affecting oil absorption capacity is protein, which is composed of both hydrophylic and hydrophobic interactions with hydrocarbon chains of lipid (Eltayeb et al. 2011). Therefore the increasing of oil absorption capacity in HMT starch could be due to lipophilic nature on the granule surface and interior during HMT which were influenced for functional properties of starches (Babu and Parimalavalli, 2012).

The paste clarity of modified starches were lower than their native starches. The same result was obtained by Singh et al. (2005) and Adebowale et al. (2005). The highest paste clarity was found in HMT starch of white tuber sweet potato. There was a correlation found between the clarity of HMT starch pastes and the whiteness of their starches $(0.969, P<0.05)$. The starch paste clarity can be influenced by the interaction of several factors such as botanical source, particle size of granules, total solids concentration, degree of granule dispersion, and the capacity of granules to form aggregates (Amani et al. 2005) which have not been examined in this study. However the results indicated that the sweet potato starch may offer high enough paste clarity for use in food products.

Solubility in cold water of HMT starches of sweet potato are given in Table 1. The results indicate that the solubility in cold water of HMT starch from 4 varieties of sweet potato were not significantly different. The interaction between starch chains within both the amorphous and crystalline domains is responsible for the solubility of starch (Zhang et al. 2005). HMT will increase the starch solubility by an increase in the low molecular weight linear fraction with hydroxyl groups that facilitated sulubilization in hot water (Güzel and Sayar, 2010; Campechano-Carrera et al. 2007).

\section{Pasting properties}

As shown in Table 2, after heat-moisture treatment, there was a marked increase in the peak viscosity (except in starch from white tuber sweet potato), a low decrease on breakdown viscosity and an increase of setback and final viscosity. The low breakdown and the high viscosity is a desireable property of starch because its paste has a noncohesive texture suitable for many food and industrial application (Singh et al. 2005).

The tendency of starch retrogradation can be predicted by using setback viscosity value. Table 2 shown that HMT increased setback viscosity values, indicating that the starch is easier to retrograde (Mali et al. 2003; Peroni et al. 2006). The higher peak viscosity of the starch was attributed to the high phosphorous and lower amylose content, which caused the higher swelling (Zaidul et al. 2007). The high viscosity of sweet potato starches would make them very useful in food application where high thickening power is desired as well as the small particle size being useful for noodle or bread production (Aprianita et al. 2009). 


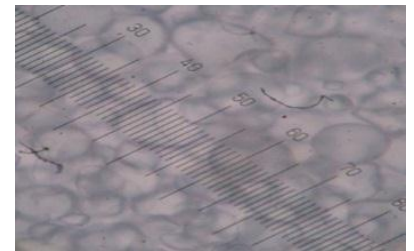

a. Native Starch of White Tuber Sweet Potato

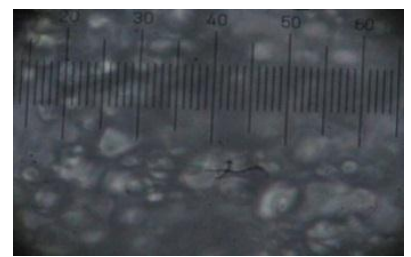

c. Native Starch of Orange Tuber Sweet Potato

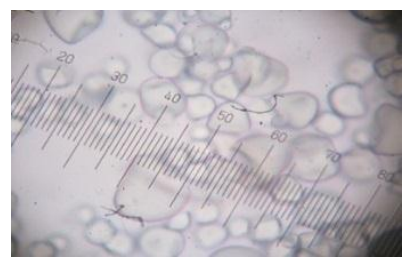

e. Modified Starch of White Tuber Sweet Potato

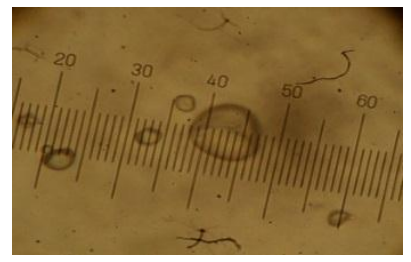

g. Modified Starch of Orange

Tuber Sweet Potato

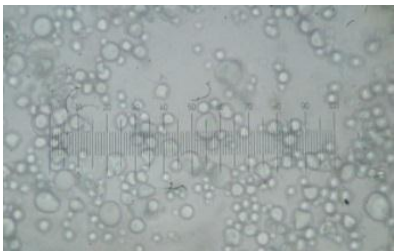

b. Native Starch of Yellow Tuber Sweet Potato

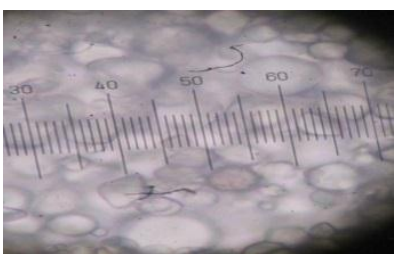

d. Native Starch of Purple Tuber Sweet Potato

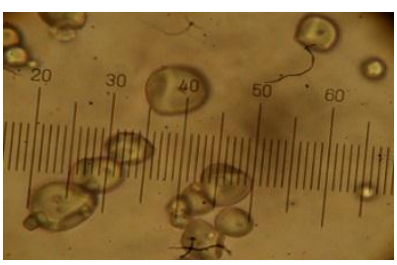

f. Modified Starch of Yellow Tuber Sweet Potato

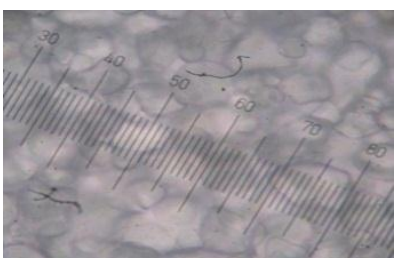

h. Modified Starch of Purple Tuber Sweet Potato

Figure 1. Light microscopy of starch granules from native and HMT process of 4 sweet potato varities

Table 2. Effect of HMT on pasting properties of starch

\begin{tabular}{|c|c|c|c|c|c|}
\hline \multirow{2}{*}{$\begin{array}{l}\text { Pasting } \\
\text { Properties }\end{array}$} & \multirow[b]{2}{*}{ Starch } & \multicolumn{4}{|c|}{ Variety of Sweet Potato } \\
\hline & & $\begin{array}{l}\text { White } \\
\text { tuber }\end{array}$ & $\begin{array}{l}\text { Yellow } \\
\text { tuber }\end{array}$ & $\begin{array}{l}\text { Orange } \\
\text { Tuber }\end{array}$ & $\begin{array}{l}\text { Purple } \\
\text { Tuber }\end{array}$ \\
\hline Peak & Native & $7810.40^{a}$ & $7297.80^{a}$ & $7574.00^{a}$ & $6459.60^{a}$ \\
\hline $\begin{array}{l}\text { Viscosity } \\
\text { (cP) }\end{array}$ & Modified & $4924.20^{b}$ & $7325.80^{a}$ & $7704.00^{a}$ & $7613.60^{a}$ \\
\hline Breakdown & Native & $4950.40^{a}$ & $5247.60^{a}$ & $3940.00^{a}$ & $4201.40^{a}$ \\
\hline $\begin{array}{l}\text { Viscosity } \\
\text { (cP) }\end{array}$ & Modified & $1342.20^{b}$ & $4504.40^{b}$ & $3039.80^{\mathrm{b}}$ & $3904.80^{b}$ \\
\hline Setback & Native & $1272.20^{a}$ & $1158.40^{a}$ & $1625.20^{a}$ & $1203.60^{a}$ \\
\hline $\begin{array}{l}\text { Viscosity } \\
\text { (cP) }\end{array}$ & Modified & $1554.60^{a}$ & $1363.40^{\mathrm{a}}$ & $1926.20^{a}$ & $1257.80^{a}$ \\
\hline Cold Paste & Native & $4132.60^{a}$ & $3208.60^{b}$ & $5259.20^{b}$ & $3461.80^{b}$ \\
\hline $\begin{array}{l}\text { Viscosity } \\
\text { (cP) }\end{array}$ & Modified & $5136.60^{b}$ & $4184.80^{a}$ & $6590.40^{a}$ & $4966.60^{a}$ \\
\hline Gela- & Native & $72.47^{a}$ & $70.05^{a}$ & $70.85^{a}$ & $69.84^{a}$ \\
\hline $\begin{array}{l}\text { tinization } \\
\text { Temp. }\left({ }^{\circ} \mathrm{C}\right)\end{array}$ & Modified & $75.71^{a}$ & $71.01^{a}$ & $71.99^{a}$ & $70.83^{a}$ \\
\hline
\end{tabular}

Means in a raw for each variety with the same letters between native and modified starch were not significantly different at $p<0.05$. All the values were the mean of 5 measurements

There is a difference results obtained in this study from the previous studies. The peak viscosity of HMT starches in this study was higher than in a native one except in HMT starch of

white tuber sweet potato, while in the previous study HMT will decrease the peak viscosity of starch and an increase in cold paste viscosity (Singh et al. 2005; Tsakama, 2011; Pukkahuta and Varavinit, 2007). This is probably due to the amount of water added to the process of modification was not sufficient to cause pregelatinized. HMT starch characteristics were influenced by the differences of process condition such as temperature (Adebowale and Lawal, 2003; Vermeylen et al. 2006; Pukkahuta and Varavinit, 2007), moisture content (Adebowale et al. 2005) and processing time (Collado and Corke, 1999).

\section{Bihon-type noodles evaluation}

Cooking and textural qualities are two main atrributes of bihon type noodles The characteristics of bihon-type noodles of HMT starch from 4 varieties of sweet potato shown in Table 3. There was no siginificant difference between HMT starch from 4 varieties of sweet potato on ash, lipid, protein content and water uptake, but there was a significant difference $(P<0.05)$ on crude fibre content, cooking loss, texure and color of bihon-type noodle as shown in Table 3. The lowest cooking loss found in bihon type noodle made from HMT starch of white tuber sweet potato, but the highest elongation found in bihon type noodle made from HMT starch of purple tuber. There is a correlation between peak viscosity of HMT starch and cooking loss of bihon-type noodle $(r=0.943, p<0.05)$. This indicated that cooking loss of bihon-type noodles will be increased as increasing of peak viscosity.

Table 3. Physicochemical properties of bihon-type noodles of HMT starch from 4 varieties of sweet potato

\begin{tabular}{|c|c|c|c|c|}
\hline $\begin{array}{l}\text { Parameter } \\
\text { of Bihon } \\
\text { Quality }\end{array}$ & $\begin{array}{l}\text { HMT Starch } \\
\text { of White } \\
\text { Tuber Sweet } \\
\text { Potato }\end{array}$ & $\begin{array}{c}\text { HMT Starch } \\
\text { of Yellow } \\
\text { Tuber Sweet } \\
\text { Potato }\end{array}$ & $\begin{array}{l}\text { HMT Starch } \\
\text { of Orange } \\
\text { Tuber Sweet } \\
\text { Potato }\end{array}$ & $\begin{array}{l}\text { HMT Starch } \\
\text { of Purple } \\
\text { Tuber Sweet } \\
\text { Potato }\end{array}$ \\
\hline $\begin{array}{l}\text { Mositure } \\
(\% \mathrm{db})\end{array}$ & 11.29 & 8.22 & 6.25 & 11.12 \\
\hline Ash (\%db) & $1.32 \pm 0.01^{a}$ & $1.33 \pm 0.01^{a}$ & $1.33 \pm 0.01^{a}$ & $1.34 \pm 0.01^{a}$ \\
\hline Lipid (\%db) & $1.40 \pm 0.10^{a}$ & $1.42 \pm 0.03^{a}$ & $1.36 \pm 0.01^{a}$ & $1.46 \pm 0.02^{\mathrm{a}}$ \\
\hline $\begin{array}{l}\text { Protein } \\
(\% \mathrm{db})\end{array}$ & $1.68 \pm 0.02^{a}$ & $1.73 \pm 0.07^{a}$ & $1.69 \pm 0.02^{\mathrm{a}}$ & $1.75 \pm 0.03^{a}$ \\
\hline $\begin{array}{l}\text { Crude } \\
\text { Fiber } \\
(\% \mathrm{db})\end{array}$ & $0.56 \pm 0.03^{d}$ & $0.77 \pm 0.01^{c}$ & $1.03 \pm 0.05^{b}$ & $1.73 \pm 0.13^{a}$ \\
\hline $\begin{array}{l}\text { Water } \\
\text { Uptake } \\
(\%)\end{array}$ & $97.91 \pm 0.49 a$ & $98.20 \pm 0.42^{\mathrm{a}}$ & $96.92 \pm 2.91^{\mathrm{a}}$ & $98.41 \pm 0.66^{a}$ \\
\hline $\begin{array}{l}\text { Cooking } \\
\text { Loss (\%) }\end{array}$ & $20.63 \pm 0.38^{d}$ & $31.24 \pm 0.77^{c}$ & $36.58 \pm 0.36^{a}$ & $30.84 \pm 1.33^{b}$ \\
\hline $\begin{array}{l}\text { Texture } \\
\text { (Elonga- } \\
\text { tion,\%E) }\end{array}$ & $27.20 \pm 2.29 b$ & $24.74 \pm 2.57^{c}$ & $17.45 \pm 1.75^{d}$ & $34.90 \pm 0.73^{a}$ \\
\hline $\begin{array}{l}\text { Color } \\
\text { (L value) }\end{array}$ & $37.06 \pm 0.45^{a}$ & $35.04 \pm 0.59 \mathrm{~b}$ & $30.66 \pm 0.30^{c}$ & $22.78 \pm 0.27^{d}$ \\
\hline
\end{tabular}

Samples means for each parameter quality followed by the same letter are not significantly different at $\mathrm{P}<0.05$ (DMRT Test). Each value is a mean of 5 replicates and \pm standard deviation

The $L$ value (lightness) is the attribute that play important roles in the appearance of bihon type noodles. The $L$ value of bihon-type noodles at various varities of sweet potato was significant difference (Table 3). It was found that the whiteness of HMT starch had a high significant correlation with the $L$ value $(r=0.992, p<0.01)$ of bihon type noodles. There is also a 
negative correlation between ash content and $L$ value of bihon type noodles $(r=-0.921, p<0.01)$. This indicated that bihon-type noodle with high ash content had low in lightness ( $L$ value), because ash expressed the fine fibers or pigments remaining in starch after isolation which could be browned after drying. The transparent noodles were perceived as high quality product by consumers (Tan et al. 2009), therefore bihon-type noodled made from HMT starch of white tuber sweet potato was found to suitable for producing good quality of noodles.

\section{Sensory evaluation of bihon-type noodles}

Sensory properties of bihon-type noodle of HMT starch from 4 varities of sweet potato shown in Table 4 . There was no significant difference on texture and taste from each other. There is a correlation between elongation and the panelist preference of texture $(r=0.81, p<0.05)$. This indicated that panelists preferred the bihon type noodles with more extensibility. The bihon made from HMT starch of yellow tuber sweet potato had a highest score for color than other varieties. Most panelist were not familiar with the color of bihon from HMT starches of sweet potato, and it makes they do not like its color.

Table 4. Sensory Evaluation of bihon-type noodles of HMT starch from 4 varieties of sweet potato

\begin{tabular}{lcccc}
\hline & $\begin{array}{c}\text { HMT Starch of } \\
\text { White Tuber } \\
\text { Sweet Potato }\end{array}$ & $\begin{array}{c}\text { HMT Starch of } \\
\text { Yellow Tuber } \\
\text { Sweet Potato }\end{array}$ & $\begin{array}{c}\text { HMT Starch of } \\
\text { Orange Tuber } \\
\text { Sweet Potato }\end{array}$ & $\begin{array}{c}\text { HMT Starch of } \\
\text { Purple Tuber } \\
\text { Sweet Potato }\end{array}$ \\
\hline Taste & $3.08 \pm 0.17^{\mathrm{a}}$ & $3.13 \pm 0.15^{\mathrm{a}}$ & $2.88 \pm 0.17^{\mathrm{a}}$ & $3.07 \pm 0.21^{\mathrm{a}}$ \\
Color & $3.00 \pm 0.19^{\mathrm{b}}$ & $3.13 \pm 0.19^{\mathrm{a}}$ & $3.07 \pm 0.08^{\mathrm{a}}$ & $2.89 \pm 0.07^{\mathrm{b}}$ \\
Texture & $3.10 \pm 0.11^{\mathrm{a}}$ & $3.08 \pm 0.07^{\mathrm{a}}$ & $2.96 \pm 0.10^{\mathrm{a}}$ & $3.09 \pm 0.17^{\mathrm{a}}$
\end{tabular}

Samples means for each sensory attribute followed by the same lette are no significantly different at $\mathrm{P}<0.05$ (DMRT Test). Each value is a mean of 5 replicates and \pm standard deviation

\section{CONCLUSION}

Modified starch with HMT on four varieties of sweet potato starch can increase peak viscosity except inwhite tuber of sweet potato starch, setback viscosity, final viscosity, and temperature of gelatinization of starch but lowers the value of the viscosity breakdown. The decline in the value of viscosity breakdown in the modified starch showed that starch granules become stronger and resistant to pressure and heat. High viscosity with a low breakdown is expected properties of starch as its pastes had a non-cohesive texture and making it suitable for most food products and industrial applications. The best varities of sweet potato for making Bihon-type noodles was whitetuber sweet potato which modified by heat moisture treatment, because it has the lower cooking loss and higher color/brightness and preferred by consumer.

\section{ACKNOWLEDGEMENT}

We wish to thank PT. Indofood Sukses Nugraha, for the research funding through "Indofood Riset Nugraha 2011".

\section{REFERENCES}

[AACC] American Association of Cereal Chemists International. 1995. Approved Methods of the American Association of Cereal Chemists. 9th ed. Method 44-15 approved October 1975, revised October 1981; Method 16-20 approved November 1989. St. Paul, Minn. American Association of Cereal Chemists.

[AACC] American Association of Cereal Chemists International. 2000. Approved Methods of the American Association of Cereal Chemists: Method 66-50 (10 ed.). St. Paul, Minn: American Association of Cereal Chemists.

Abdoulaye S, Yao WR, Wang H, Qian H, Sangare M. 2012. The yield improvement of resistant starches from Africa locust (Parkia biglobosa): The influence of heat-moisture, autoclaving-cooling and cross-linking treatments. Am J Food Tech 7: 386-397. DOI: 10.3923/ajft.2012.386.397.

Adebowale KO, Lawal OS. 2003. Microstructure, physicchemical properties and retrogradation behaviour of Mucuna bean (Mucuna pruriens) starch on heat moisture treatments. Food Hydrocolloid 17: 265-272.

Adebowale KO, Lawal OS. 2004. Comparative study of the functional properties of bambara groundnut (Voandzeia subterranean), jack bean (Cana valiaensiformis) and mucuna bean (Mucuna pruriens) flour. Food Res Int 37: 355-365.

Adebowale, KO, Olu-Owolabi BI, Olayinka OO, Lawal OS. 2005. Effect of heat moisture treatment and annealing on physicochemical properties of red sorghum starch. Afr $\mathrm{J}$ Biotechnol 4: 928-933.

[AOAC] Association of Official Analytical Chemists. 1995. Official Methods of Analysis of The Association of Official Analytical Chemists. Washington: AOAC.

Aina AJ, Falade KO, Akingbala JO, Titus P. 2012. Physicochemical properties of Carribean sweet potato (Ipomoea batatas(L) Lam) Starches. Food Bioprocess Tech 5: 576-583. DOI: 10.1007/s11947009-0316-6.

Ali N, Falade KO, Akingbala JO. 2012. Effect of cultivar on quality attributes of sweet potato fries and crisps. Food Nut Sci 3: 224-232. DOI : 10.4236/fns.2012.32033.

Amani NGG, Kamenan A, Sabate AR, Colonna P. 2005. Stability of yam starch during processing. Afr J Biotechnol 4: 94-101.

Aparicio-Saguilan A, Flores-Huicochea E, Tovar J, GarciaSuarez F, Gutierrez-Meraz F, Bello-Perez LA. 2005. Resistant starch-rich powder prepared by autoclaving of native and lintnerized banana starch: Partial characterization. Starch-Starke 57: 405-412. DOI: 10.1002/ star.200400386.

Aprianita A, Purwandari U, Watson B, Vasiljevic T. 2009. Physico-chemical properties of flours and starches from selected commercial tubers available in Australia. Int Food Res J 16: 507-520. 
Babu AS, Parimalavalli R. 2012. Functional and chemical properties of starch isolated from tubers. Int $\mathrm{J}$ Agric Food Sci 2: 77-80.

[BSN] National Standarization Agency of Indonesia. 1989. SNI 06-1451-1989. Dextrin for non Food Industry.

Campechano-Carrera E, Corona-Cruz A, Chel-Guerrero L, Betancur-Ancona D. 2007. Effect of pyrodextrinization on available starch content of lima bean (Phaseolus lunatus) and cowpea (Vigna unguiculata) starches. Food Hydrocoloid 21: 472-479. DOI: 10.1016/j.foodhyd.2006.06.006.

Ceballos H, Sanchez N, Morante M, Fregene D, Dufour A, Smith K, Denyer J, Perez F, Calle C, Mesters. 2007. Discovery of an amylose-free starch mutant in cassava (Manihot utilissima Crantz). J Agric Food Chem 55: 74697476. DOI: 10.1021/jf070633y.

Chen Z, Schols HA, Voragen AGJ. 2003. Physicochemical properties of starches obtained from three varieties of Chinese sweet potatoes. J Food Sci 68: 431-437. DOI: 10.1111/j.1365-2621.2003.tb05690.x.

Collado LS, Corke H. 1999. Heat-moisture treatment effects on sweet potato starches differing in amylose content. Food Chem 65: 339-346. DOI: 10.1016/S0308-8146(98)00228-3.

Collado LS, Mabesa LB, Oates CG, Corke H. 2001. Bihon-type noodles from heat moisture-treated sweet potato starch. $\mathrm{J}$ Food Sci 66: 604-609. DOl: 10.1111/j.1365-2621.2001. tb04608.x.

Eltayeb ARSM, Ali AO, Abou-Arab AA, Abu Salem FM. 2011. Chemical composition and functional properties of flour and protein isolate extracted from Bambara groundnut (Vigna subterranean). Afr J Food Sci 5: 82-90.

Güzel D, Sayar S. 2010. Digestion profiles and some physicochemical properties of native and modified borlotti bean, chickpea and white kidney bean starches. Food Res Int 43: 2132-2137. DOI: 10.1016/j.foodres.2010.07.025.

Huang CC, Lin MC, Wang CCR. 2006. Changes in morphological, thermal, and pasting properties of yam (Discorea alata) starch during growth. Carbohyd Polym 64: 524-531. DOI: 10.1016/i.carbpol.2005.11.009.

Haghayegh G, Schoenlechner R. 2011. Physically modified starches : A review. J Food Agric Environ 9: 27-29.

[IPC] International Potato Center. 2011. Sweet Potato. http://www.cipotato.org/sweetpotato. [30th December 2012].

Julianti E, Ridwansyah. 2008. Physicochemical Properties of Starch Obtained from four Varieties of Sweet Potato. Proceeding National Seminar of "BKS Barat Bidang IImuIImu Pertanian", Banda Aceh 22-24 Juli 2008.

Kitahara K, Fukunaga S, Katayama K, Takanata Y, Nakazawa Y, Yoshinaga M, Suganuma T. 2005. Physicochemical properties of sweet potato starches with different gelatinization temperatures. Starch-Starke 57: 473-479. DOI: $10.1002 /$ star.200400349.

Koksel H, Ozturk S, Kahraman K, Basman, A, Ozbas 00, Ryu $\mathrm{GH}$. 2008. Evaluation of molecular weight distribution, pasting and functional properties, and enzyme resistant starch content of acid-modified corn starches. Food Sci Biotechnol 17: 755-760.
Lee $H$, Shin M. 2006. Comparison of the properties of wheat flours supplemented with various dietary fibers. Food Sci Biotechnol 15: 746-751.

Mali S, Ferrero C, Redigonda V, Beleia AP, Grossmann MVE, Zaritzky NE. 2003. Influence of $\mathrm{pH}$ and hydrocolloids addition on yam (Dioscoria alata) starch pastes stability. Lebensm Wiss Technol 36: 475-481. DOl: 10.1016/S00236438(03)00043-4.

Matos M, Perez E, Pacheco E. 2009. Effect of heating on the ultrastructure of sweet potato (Ipomoea batatas L.) starch. Rev Fac Agron (UCV) 35: 15-20.

Muazu J, Musa H, Isah AB, Bhatia PG, Tom GM. 2011. Extraction and characterization of kuffar potato starch : A potential source of pharmaceutical raw material. J Nat Prod Plant Resour 1: 41-49.

Odeku OA. 2013. Potential of tropical starches as pharmaceutical excipients : A review. Starch-Starke 65: 89106. DOI: $10.1002 /$ star.201200076.

Oladebeye AO, Oshodi AA, Oladebeye AA. 2009. Physicochemical properties of starches of sweet potato (Ipomoea batata) and red cocoyam (Colocasia esculenta) Cormels. Pakistan J Nut 8: 313-315. DOI: 10.3923/pin. 2009.313.315.

Onyango C, Bley T, Jacob A, Henle T, Rohm H. 2006. Influence of incubation temperature and time on resistant starch type III formation from autoclaved and acid-hydrolysed cassava starch. Carbohydrate Polym 66: 494-499. DOI: 10.1016/i.carbpol.2006.04.002.

Peroni FHG, Rocha TS, Franco CML. 2006. Some structural and physicochemical characteristics of tuber and root starches. Food Sci Tech Int 12: 505-513. DOI: 10.1177/1082013206073045.

Pukkahuta C, Varavinit S. 2007. Structural Transformation of Sago Starch by Heat-Moisture and Osmotic-Pressure Treatment. Starch-Starke 59: 624-631. DOI: 10.1002/star .200700637.

Pukkahuta C, Suwannawat B, Shobsngob S, Varavinit S. 2008. Comparative study of pasting and thermal transiton characteristics of osmotic pressure and heat-moisture treated corn starch. Carbohyd Polym 72: 527-536. DOl: 10.1016/j.carbpol.2007.09.024.

Purwani EY, Widianingrum, Thahir R, Muslich. 2006. Effect of heat moisture treatment of sago starch on its noodle quality. Indonesian J Agr Sci 7: 8-14.

Sajilata MG, Singhal RS, Kulkarni PR. 2006. Resistant starch: A review. Compre Rev Food Sci F 5: 1-17.

Singh S, Raina CS, Bawa AS, Saxena DC. 2005. Effect of heatmoisture treatment and acid modification on rheological, textural, and differential scanning calorimetry characteristics of sweet potato starch. J Food Sci 70: e373-e377. DOI: 10.1111/j.1365-2621.2005.tb11441.x.

Statistics Indonesia of Republic Indonesia. 2012. Table of harvested area- productivity- production sweet potato in all provinces. www.bps.go.id. [September $8^{\text {th }}$ 2012]. 
Takashi T, Miura M, Ohisa N, Mori K, Kobayashi S. 2005. Heat treatments of milled rice and properties of the flours. Cereal Chem 82: 228-232. DOI: 10.1094/CC-82-0228.

Tan HZ, Li ZG, Tan B. 2009. Starch noodles: History, classification, materials, processing, structure, nutrition, quality evaluating and improving. Food Res Int 42: 551-576. DOl: 10.1016/i.foodres.2009.02.015.

Thao HM, Noomhorm A. 2011. Physicochemical properties of sweet potato and mung bean starch and their blends for noodle production. J Food Process Technol 2: 1-9. DOI: 10.4172/2157-7110.1000105.

Tsakama M, Mwangwela AM, Manani TA, Mahungu NM. 2011. Effect of heat moisture treatment on physicochemical and pasting properties of starch extracted from eleven sweet potato varieties. Int Res J Agr Sci Soil Sci 1: 254-260.
Vermeylen R, Goderis B, Delcour JA. 2006. An X-ray study of hydrothermally treated potato starch. Carbohyd Polym 64: 364-375. DOl: 10.1016/j.carbpol.2005.12.024.

Zaidul ISM, Norulaini NAN, Omar AKM, Yamauchi H, Noda T. 2007. RVA analysis of mixtures of wheat flour and potato, sweet potato, yam, and cassava starches. Carbohyd Polym 69: 784-791. DOI: 10.1016/i.carbpol.2007.02.021.

Zhang P, Whistler R, BeMiller JN, Hamaker, BR. 2005. Banana starch: production, physicochemical properties, and digestibility - a review. Carbohyd Polym 59: 443-458. DOI: 10.1016/i.carbpol.2004.10.014.

Zhu F, Yang XS, Cai YZ, Bertoft E, Corke H. 2011. Physicochemical properties of sweet potato starch. Starch-Starke 63: 249-259. DOl: 10.1002/star.201000134. 